\title{
Resistance Response of the Recently Discovered Species Nicotiana mutabilis to Potato virus Y (PVY) and Tomato spotted wilt virus (TSWV) Compared to Other Sources of Resistance
}

\author{
Anna Depta*D, Teresa Doroszewska (D) and Anna Czubacka \\ Institute of Soil Science and Plant Cultivation-State Research Institute, Czartoryskich 8 Str., \\ 24-100 Puławy, Poland; dorter@iung.pulawy.pl (T.D.); annacz@iung.pulawy.pl (A.C.) \\ * Correspondence: adepta@iung.pulawy.pl
}

check for updates

Citation: Depta, A.; Doroszewska, T.; Czubacka, A. Resistance Response of the Recently Discovered Species Nicotiana mutabilis to Potato virus $Y$ (PVY) and Tomato spotted wilt virus (TSWV) Compared to Other Sources of Resistance. Agronomy 2021, 11, 1617. https://doi.org/10.3390/ agronomy11081617

Academic Editor: Vicente J. Febres

Received: 15 July 2021

Accepted: 12 August 2021

Published: 14 August 2021

Publisher's Note: MDPI stays neutral with regard to jurisdictional claims in published maps and institutional affiliations.

Copyright: (c) 2021 by the authors. Licensee MDPI, Basel, Switzerland. This article is an open access article distributed under the terms and conditions of the Creative Commons Attribution (CC BY) license (https:// creativecommons.org/licenses/by/ $4.0 /)$.

\begin{abstract}
Nicotiana mutabilis is a recently discovered species within the genus Nicotiana. The aim of the present study was to evaluate its resistance to Potato virus Y (PVY) and Tomato spotted wilt virus (TSWV). Molecular analysis was performed to detect the Va gene determining susceptibility to PVY and the SCAR marker associated with resistance to TSWV. Resistance tests were carried out under greenhouse conditions through artificial inoculation with one TSWV and two PVY isolates. In order to confirm the presence of the viruses in plants, DAS-ELISA tests were performed using antibodies against PVY and TSWV. The results indicated the absence of the PVY susceptibility gene and the presence of the TSWV resistance gene in the genome of N. mutabilis. This species was considered tolerant to the two PVY isolates tested because, despite the positive DAS-ELISA results, the infected plants showed vein clearing and chlorotic spots but no vein necrosis. As a result of TSWV inoculation, $N$. mutabilis showed a hypersensitive response; however, after four months, $30 \%$ of the inoculated plants showed systemic infection. This species extends the genetic variation in the genus Nicotiana and, because of its tolerance to PVY and partial resistance to TSWV, it may be a potential source of resistance to these viruses.
\end{abstract}

Keywords: resistance; tolerance; va gene; SCAR marker

\section{Introduction}

Species of the genus Nicotiana, a member of the Solanaceae family, occur naturally throughout North and South America, Australia and Africa [1]. Individual species have been discovered and described over many years [2-5]. A great contribution to Nicotiana studies was made by T.H. Goodspeed [3], who also developed the Nicotiana classification that has been in force for more than 50 years. His research was based mainly on morphology and cytology and his classification of Nicotiana divided the genus into 3 subgenera and 14 sections. The current systematics of the genus Nicotiana has been developed based on molecular studies and indicates the existence of 76 species divided into 13 sections [6]. There are some discrepancies, however, regarding the number of species. Lewis and Nicholson reported that the genus Nicotiana had 70 species, as the rest were merely synonyms to other species within the genus [7]. The most recently discovered species of the genus Nicotiana, found in southern Brazil, is Nicotiana mutabilis. Under natural conditions, this species grows on forest edges, roadsides and abandoned fields. It is pollinated in the morning and evening hours by hummingbirds and has been shown to have 18 chromosomes and to be self-compatible. It has been included in the section Alatae [8].

Wild Nicotiana species are characterised by very high variability related to their occurrence, morphology and chromosome number. They also constitute a valuable reservoir of resistance/tolerance genes to biotic and abiotic factors [1].

Viral diseases pose a significant threat to tobacco cultivation because chemical protection is limited only to vector control. The duration of vector feeding and virus transmission, 
however, is not always long enough for chemical protection to be effective. Many viral diseases are also developed due to mechanical infection. The most efficient way to counteract diseases, especially viral ones, is to develop genetic resistance. For this purpose, breeding work using desirable sources of resistance is necessary [9].

An economically important viral disease of tobacco is tobacco veinal necrosis, caused by Potato virus Y (PVY). This virus is transmitted by aphids in a non-persistent manner. Disease symptoms initially include vein clearing and chlorotic spots, followed by vein necrosis on the leaves. This results in a significant reduction in yield and in the quality of the dried raw material $[10,11]$. Potato virus $Y$, which belongs to the genus Potyvirus, of the family Potyviridae [12,13], has a single sense RNA strand of about 9700 nucleotides in length $[14,15]$. Potato virus $Y$ exists as a complex of strains, including a growing number of recombinants [16-18]. The classification of PVY isolates depends on biological, serological and molecular characteristics. According to the host from which they were originally collected, isolates have been classified into four different strains, corresponding to potato, pepper, tobacco and tomato strains. Based on the symptoms induced on tobacco and potatoes, $\mathrm{PVY}$ isolates have been divided into three main strains, $\mathrm{PVY}{ }^{\mathrm{O}}, \mathrm{PVY}^{\mathrm{C}}$ and $P V Y^{\mathrm{N}}[17,18]$. The $\mathrm{PVY}^{\mathrm{O}}$ strain (ordinary or common strain) induces a systemic mosaic in most potato cultivars and mild symptoms in tobacco cultivars. The PVYC strain causes stipple streak symptoms on potato cultivars, carrying the $N$ s resistance gene and non-necrotic symptoms on tobacco. The PVYN strain induces veinal necrosis on $N$. tabacum and very mild mottling with occasional necrotic leaves on potato cultivars [19,20]. Isolates from the group PVY ${ }^{\mathrm{N}}$ were further divided into two subgroups, PVY ${ }^{\mathrm{N}} \mathrm{W}$ and PVYNTN, and the differentiation between them is possible by using two types of antibodies produced by the Bioreba company [21]. The PVY ${ }^{\mathrm{N}} \mathrm{Wi}$ isolate was found in the potato cultivar Wilga [17]. This strain causes tobacco veinal necrosis and possesses the capsid protein sequence of PVYO isolates. The PVYNTN isolates cause a tuber necrosis reaction on potato cultivars and vein necrosis on tobacco [20]. The variation within PVY isolates is due to numerous point mutations and recombinations between isolates [22,23]. The differentiation of the tobacco cultivars to PVY is determined by the dominant $V a$ gene, whose product, the eukaryotic translation initiation factor 4E (eIF4E), interacts with the PVY genome-linked protein (VPg) [24,25]. Resistance to PVY within cultivated tobacco is determined by a single recessive $v a$ gene resulting from a deletion of the $e I F 4 E$ gene located on chromosome 21 [26]. This deletion is a consequence of X-ray mutagenesis of the Virgin A [27] and, subsequently, this type of resistance is transferred to other tobacco cultivars through breeding. The durability of resistance determined by different types of mutations within the eIF4E gene depends on the size of the deletion [28]. There are PVY strains, however, that are capable of overcoming this resistance and infestation of varieties previously considered resistant is becoming increasingly common [29].

Some wild species of the genus Nicotiana possess resistance to PVY, therefore, they can be valuable material for resistance breeding [30,31]. Among them, Nicotiana africana, which belongs to the section Suaveolentes, deserves attention. During a study, in which more than 40 PVY isolates from tobacco and potatoes were used, this species was not infected by any of them [10,32]. Due to its immunity, N. africana has been used in breeding work. Wersman obtained an addition line, NC152, containing a pair of homologous chromosomes from N. africana, that was the result of a cross of this wild species with susceptible tobacco cultivar McNair944 [33]. This line was used by Lewis to assess the degree of gene transfer from $N$. africana both by classical breeding and by using in vitro cultures [34]. The nearly isogenic lines obtained by Lewis possessed both the recessive $v a$ gene and the Nafr fragment and showed varying levels of resistance, depending on the virulence of the used PVY isolate [35]. The chromosomal region Nafr introgressed into the tobacco genome did not provide complete resistance. Doroszewska [36] obtained the breeding line BPA $(2 \mathrm{n}=48)$ by crossing the susceptible tobacco cultivar BP-210 with N. africana. This line was characterised as tolerant, since no vein necrosis occurred regardless of the applied PVY isolate, even if the virus was present in the plants [37]. BPA and Nafr introgression lines differ in the mode 
of inheritance of PVY tolerance. According to Korbecka et al., the PVY tolerance in BPA is a recessive trait, while the Nafr gene is inherited in a partially dominant fashion $[35,38]$.

Another very important viral disease of tobacco is tomato spotted wilt caused by the Tomato Spotted Wilt Virus (TSWV), also known as Lycopersicum virus 3. This poses a significant threat to tobacco, as well as to many other species belonging to 85 botanical families [39]. This virus belongs to the genus Orthotospovirus, of the family Tospoviridae [40,41]. It is transmitted by several species of thrips [42], including tobacco thrips (Thrips tabaci). Initial disease symptoms include chlorotic and necrotic spots and, as the virus moves through the plant, there is stunted growth and a characteristic bending of the stem tip by about $45^{\circ}$ [43]. TSWV causes a decrease in the yield of leaves, their quality and their technological usefulness. High intensity of infection may even necessitate plantation liquidation. The control of thrips is the most effective disease control strategy [44]. In the case of plants that are already infected with the virus, thrip control will not stop the development of the disease but may limit further spread. The only effective method of protecting tobacco against TSWV is the cultivation of resistant cultivars [9].

Within the genus Nicotiana, the species Nicotiana alata is considered as a potential source of resistance to TSWV because it develops a hypersensitive reaction to the virus, appearing as small necrotic spots on lower leaves. The necrosis of tissues prevents movement of the virus to higher parts of the plant [45-49]. The known resistance gene against TSWV, derived from $N$. alata, has been named RTSW-al [49]. It can be identified using the SCAR markers developed by Moon and Nicholson [50].

A hypersensitive reaction also occurs in the species $N$. forgetiana, belonging to the section Alatae, which is visible especially at the initial stages of infection, but, with time, plants become systemically infected [49].

Nicotiana mutabilis, discovered in 2002 [8], is of great interest to researchers. In fact, there are limited data in the literature on this species, especially regarding its disease resistance. The objective of this study was the evaluation of the $N$. mutabilis resistance against PVY and TSWV, which are the most economically important viral diseases for tobacco. Susceptibility to PVY and TSWV was determined using the Va gene and SCAR markers, respectively. Resistance in N. mutabilis was compared to that of related species, i.e., N. alata and N. forgetiana. Two cultivars of N. tabacum were used as susceptible controls.

\section{Materials and Methods}

\subsection{Plant Material}

The experimental species were:

- Nicotiana mutabilis, section Alatae [1];

- Nicotiana alata, section Alatae;

- Nicotiana forgetiana, section Alatae;

- Nicotiana tabacum, section Nicotiana. In our research, this species was represented by two cultivars:

- Virginia A Mutant (VAM) — belongs to the light flue-cured type of tobacco [9]. Obtained by the action of $X$ rays [51]. It has $v a$ resistance and is resistant to most PVY isolates, especially from the PVYN W group [20,52-54]. It is, however, susceptible to TSWV.

- Burley 21-belongs to the light air-cured type of tobacco. Susceptible to all strains of PVY and to TSWV.

\subsection{Resistance Tests}

Biological tests aimed at assessing the resistance of the species $N$. mutabilis and other tested species to PVY and TSWV were performed by artificial inoculation in greenhouse conditions. Inoculation was carried out at the 5-6 leaf stage and three of the leaves were inoculated. Five species were used for the study and the number of tested plants depended on the species and the type of virus that was used for inoculation (Table 1). Three plants 
for each species were used as controls. Both virus-inoculated and control plants were maintained under the same conditions in the greenhouse, which were as follows:

- temperature, $24{ }^{\circ} \mathrm{C}$ during the day $/ 16^{\circ} \mathrm{C}$ at night;

- light and darkness duration, $16 \mathrm{~h}$ light/ $8 \mathrm{~h}$ darkness.

Table 1. Species tested for resistance to PVY and TSWV, as well as the presence of molecular markers.

\begin{tabular}{|c|c|c|c|c|}
\hline \multirow{2}{*}{ No. } & \multirow{2}{*}{ Species } & \multicolumn{3}{|c|}{ Number of Plants Tested with: } \\
\hline & & PVY IUNG 21 & PVY IUNG 20 & TSWV \\
\hline 1 & N. mutabilis & 20 & 20 & 40 \\
\hline 2 & N. alata & 5 & 5 & 10 \\
\hline 3 & N. forgetiana & 5 & 5 & 10 \\
\hline 4 & $\begin{array}{l}\text { N. tabacum } \mathrm{cv} \text {. } \\
\text { VAM }\end{array}$ & 5 & 5 & 10 \\
\hline 5 & $\begin{array}{l}\text { N. tabacum cv. } \\
\text { Burley } 21\end{array}$ & 5 & 5 & 10 \\
\hline
\end{tabular}

In the study for PVY resistance, two viral isolates of contrasting virulence were used:

- IUNG 21-mild isolate that does not break va resistance in the VAM cultivar. It is not detectable by monoclonal antibodies directed against the necrotic serotype (MoAbs anti $Y^{\mathrm{N}} \operatorname{IgG} 112511$, Bioreba) [21];

- IUNG 20-severe isolate that breaks the va resistance of cultivar VAM. Detectable by two types of Bioreba antibodies (MoAbs anti Y IgG 112511 and MoAbs anti YN ${ }^{\mathrm{N}}$ IgG 112512) [21].

The source of TSWV and PVY inocula for all experiments was maintained in Samsun $\mathrm{H}$ tobacco plants. All kinds of inocula were prepared from leaves with visible disease symptoms. The presence of each virus in the sap of the tested plants was assayed by DAS-ELISA (double antibody sandwich enzyme-linked immunosorbent assay). Samples of plant material with the confirmed presence of each virus (TSWV and PVY) were stored in an ultra-freezer at $-80^{\circ} \mathrm{C}$.

The PVY inoculum consisted of leaves of infected plants, ground in a mortar with a small amount of distilled water. The TSWV inoculum preparation required a phosphate buffer $\left(9.078 \mathrm{~g} / \mathrm{L}\right.$ of $\mathrm{KH}_{2} \mathrm{PO}_{4}$ and $11.867 \mathrm{~g} / \mathrm{L}$ of $\left.\mathrm{Na}_{2} \mathrm{HPO}_{4}\right)$ with $0.5 \%$ mercaptoethanol [55]. Infection of plants was carried out under the same conditions and in the same manner for both viruses. An appropriately prepared inoculum was rubbed on carborundum-strewn leaves of test plants at a volume of approximately $1 \mathrm{~mL}$ of inoculum per plant. The inoculated plants were protected from direct sunlight for $48 \mathrm{~h}$. Plants inoculated only with buffer were also included in the study for comparison with virus-inoculated plants. Observation of disease symptoms and photographic documentation were systematically performed.

\subsection{Serological Tests}

In order to confirm the presence of a particular virus in plant tissues, serological tests were performed by DAS-ELISA using antibodies manufactured by Bioreba (Switzerland) and directed against PVY (catalogue no. 112511) and TSWV (catalogue no. 190115). For PVY, tests were performed once, four weeks after inoculation. Samples for ELISA from TSWV-infected plants were collected three times-after four weeks, after eight weeks and after four months from inoculation. The following were collected from different plant parts [9]:

- lower part included four lower leaves;

- middle part included four leaves above the lower part;

- upper part included the four youngest leaves on the plant. 
DAS-ELISA tests were performed according to the manufacturer's protocol. Absorbance was measured at $405 \mathrm{~nm}$ on a Tecan Sunrise plate reader (Swizerland) $45 \mathrm{~min}$ after substrate application. The negative control was provided by the manufacturer and the positive control was a susceptible Samsun H plant infected with the appropriate virus.

\subsection{Molecular Tests}

All plants tested for resistance to viruses were used in molecular analyses (Table 1). Isolation of genomic DNA was performed according to the method by Doyle and Doyle [56]. Total DNA was isolated from $200 \mathrm{mg}$ of leaf tissue, which was previously homogenised with Qiagen Tissue Lyzer. Then, $1 \mathrm{~mL}$ of preheated (up to $60^{\circ} \mathrm{C}$ ) isolation buffer $(100 \mathrm{mM}$ Tris- $\mathrm{HCl}, 1.4 \mathrm{M} \mathrm{NaCl}, 20 \mathrm{mM}$ EDTA, $\%$ CTAB and $0.2 \% \beta$-mercaptoethanol) was added. The samples were shaken vigorously for $5 \mathrm{~s}$, incubated at $60{ }^{\circ} \mathrm{C}$ for $30 \mathrm{~min}$, then cooled to room temperature. Next, the same volume of a mixture of chloroform: isoamyl alcohol $(24: 1 \mathrm{v} / \mathrm{v})$ was added and the samples were shaken gently for $5 \mathrm{~min}$, then centrifuged for $15 \mathrm{~min}$ at $4{ }^{\circ} \mathrm{C}$ and $14,000 \mathrm{rpm}$. The upper phase was transferred to a fresh Eppendorf tube and one volume of isopropanol was added. The samples were placed at $-20{ }^{\circ} \mathrm{C}$ for $15 \mathrm{~min}$, then gently shaken and centrifuged for $15 \mathrm{~min}$. After discarding the supernatant, the remaining pellet was washed twice by pouring $600 \mu \mathrm{L}$ of $70 \%$ ethanol and centrifugation. The extracted DNA was vacuum-dried and resuspended in $20 \mu \mathrm{L}$ of sterile MiliQ water. The absorbance of samples was measured and a dilution of $20 \mathrm{ng} / \mu \mathrm{L}$ of DNA was obtained for all samples. The detection of resistance genes against PVY was carried out indirectly by detection of the susceptibility $V a$ gene. For DNA amplification, PCR reactions were performed using primers detecting marker Nsyl-elF4E1 (forward primer, 5'-AATGCTTATTGTTAGCCTTTGTTTCT-3' ; reverse primer, 5'-GTCAAGTGGCAGCCTTTCATA-3'), which amplified a 402 bp product [57]. Each $10 \mu \mathrm{L}$ of PCR reaction mixture contained $1 \mu \mathrm{L}$ of $20 \mathrm{ng} / \mu \mathrm{L}$ plant DNA and $6 \mu \mathrm{L}$ of True Allele PCR Premix buffer (Applied Biosystems, Waltham, MA, USA) containing polymerase, $0.15 \mu \mathrm{L}$ of each $10 \mu \mathrm{M}$ primer pair and $2.7 \mu \mathrm{L}$ of MiliQ sterile water. The PCR reactions included pre-denaturation for $10 \mathrm{~min}$ at $95^{\circ} \mathrm{C}$ and 44 cycles with the following profile: $1 \mathrm{~min}$ at $95^{\circ} \mathrm{C}, 1 \mathrm{~min}$ at $64{ }^{\circ} \mathrm{C}, 2 \mathrm{~min}$ at $72{ }^{\circ} \mathrm{C}$ and a final elongation for $7 \mathrm{~min}$ at $72^{\circ} \mathrm{C}$.

In order to detect the gene associated with TSWV resistance, the SCAR marker ACC/CCC 172 (forward primer, 5'-AGCTTCTTTCTCTCTTCCATTTTT-3'; reverse primer, 5'-CAGAAGAAAAACTGCTGGAGCTAT-3') [50] was amplified, giving a 117 bp product. The reaction mixture for PCR using the True Allele PCR Premix (Applied Biosystems, Waltham, MA, USA) was identical to that for the $V a$ gene. The PCR reactions included pre-denaturation for $3 \mathrm{~min}$ at $94^{\circ} \mathrm{C}$ and 35 cycles with the following profile: $1 \mathrm{~min}$ at $94{ }^{\circ} \mathrm{C}$, $1 \mathrm{~min}$ at $55^{\circ} \mathrm{C}, 2 \mathrm{~min}$ at $72{ }^{\circ} \mathrm{C}$ and a final elongation for $7 \mathrm{~min}$ at $72{ }^{\circ} \mathrm{C}$.

PCR products were analysed in $1.5 \%$ agarose gel in $1 \times$ TBE buffer $(100 \mathrm{mM}$ Tris, $90 \mathrm{mM}$ $\mathrm{H}_{3} \mathrm{BO}_{3}, 1 \mathrm{mM}$ EDTA, $\mathrm{pH}$ of 8.5). The visualisation of electrophoretic separation results was performed in a transilluminator under UV light.

\section{Results}

\subsection{Resistance Response to PVY}

The tested species showed differences in symptom severity to PVY depending on the isolate used (Table 2). Nicotiana mutabilis, when infected with IUNG 20 (severe) and IUNG 21 (mild) isolates, showed vein clearing and no necrosis (Figure 1a). This symptom appeared 21 days post inoculation (dpi) and no other symptoms of disease occurred subsequently. The virus was detected by immunoassay four weeks after inoculation. In addition, in related species, N. alata and N. forgetiana, vein clearing was observed at $21 \mathrm{dpi}$. No additional disease symptoms were observed in N. alata. In N. forgetiana, the mild PVY isolate IUNG 21 caused vein clearing and leaf wrinkling at $28 \mathrm{dpi}$, while the severe PVY isolate IUNG 20 additionally caused mosaic leaf symptoms within the same length of time. Among the tested cultivars of Nicotiana tabacum, there were differences in response depending on the isolate used. Cultivar Burley 21, inoculated with the mild isolate, reacted 
with vein clearing at $14 \mathrm{dpi}$ and vein necrosis at $21 \mathrm{dpi}$. Inoculation with the severe PVY isolate, however, resulted in vein clearing earlier, at $7 \mathrm{dpi}$, and vein necrosis at $14 \mathrm{dpi}$. In cultivar Burley 21, the DAS-ELISA test gave a positive result after inoculation with the two isolates. In contrast, the cultivar VAM showed no disease symptoms after inoculation with the mild isolate, while the application of the severe isolate resulted in vein necrosis at $21 \mathrm{dpi}$ (Figure 1b). For this cultivar, the virus was detected in the sap of plants infected only with the severe isolate. Plants inoculated only with buffer showed no disease symptoms (Figure 1c).

Table 2. Presence of the Nsyl-elF4E1 marker characteristic for the $V a$ gene responsible for susceptibility and the reaction of the tested species after inoculation with two PVY isolates.

\begin{tabular}{|c|c|c|c|c|c|}
\hline \multirow{3}{*}{ Species } & \multirow{3}{*}{$\begin{array}{l}\text { Presence of Marker } \\
\text { Nsyl-elF4E1 }\end{array}$} & \multicolumn{4}{|c|}{ PVY Isolate } \\
\hline & & \multicolumn{2}{|c|}{ IUNG 21 (Mild) } & \multicolumn{2}{|c|}{ IUNG 20 (Severe) } \\
\hline & & Symptoms & $\begin{array}{c}\text { DAS-ELISA } \\
\text { Results }\end{array}$ & Symptoms & $\begin{array}{c}\text { DAS-ELISA } \\
\text { Results }\end{array}$ \\
\hline Nicotiana mutabilis & - & $\mathrm{VC}$ & + & $\mathrm{VC}$ & + \\
\hline Nicotiana alata & - & $\mathrm{VC}$ & + & $\mathrm{VC}$ & + \\
\hline Nicotiana forgetiana & - & $\mathrm{VC}, \mathrm{WL}$ & + & VC, WL, MS & + \\
\hline $\begin{array}{c}\text { Nicotiana tabacum } \\
\text { cv. VAM }\end{array}$ & - & ns & - & VN & + \\
\hline $\begin{array}{l}\text { Nicotiana tabacum } \\
\text { cv. Burley } 21\end{array}$ & + & VN & + & $\mathrm{VN}$ & + \\
\hline
\end{tabular}

Legend: ns, no symptoms; VN, vein necrosis; VC, vein clearing; WL, wrinkled leaves; MS, mosaic symptoms; (+) positive, (-) negative results of the DAS-ELISA test.PVY isolates: IUNG 21, mild isolate that does not break va resistance in the VAM cultivar. It is not detectable by monoclonal antibodies directed against the necrotic serotype (MoAbs anti $Y^{\mathrm{N}} \operatorname{IgG} 112511$, Bioreba). IUNG 20, severe isolate that breaks the $v a$ resistance of cultivar VAM. Detectable by two types of antibodies (MoAbs anti Y IgG 112511 and MoAbs anti YN IgG 112512, Bioreba).

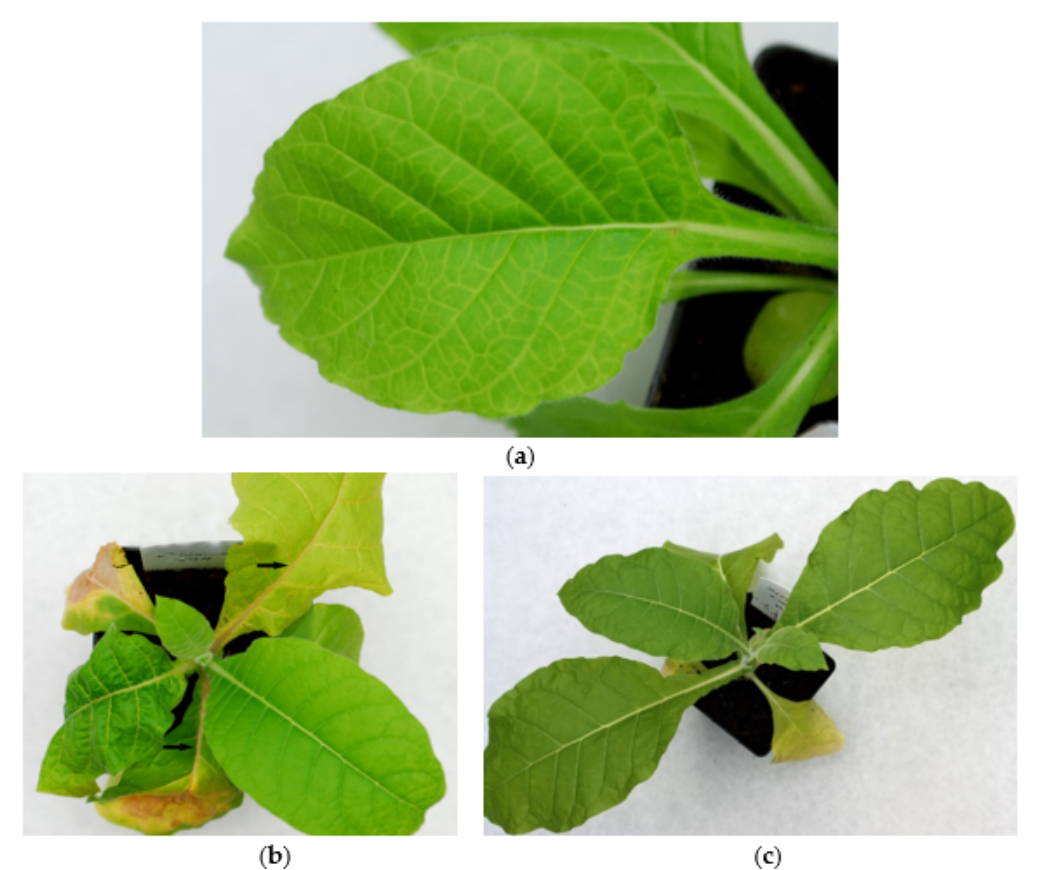

Figure 1. Resistance response of the tested species to the severe PVY isolate four weeks after inoculation: (a) vein clearing on leaves of N. mutabilis; (b) vein necrosis on tobacco cultivar VAM (indicated by black arrows); (c) control plant of cultivar VAM inoculated only with buffer.

Among the tested species, only N. tabacum cv. Burley 21 amplified the Nsyl-elF4E1 marker, which indicated the presence of the $V a$ susceptibility gene in this cultivar (Figure 2). 


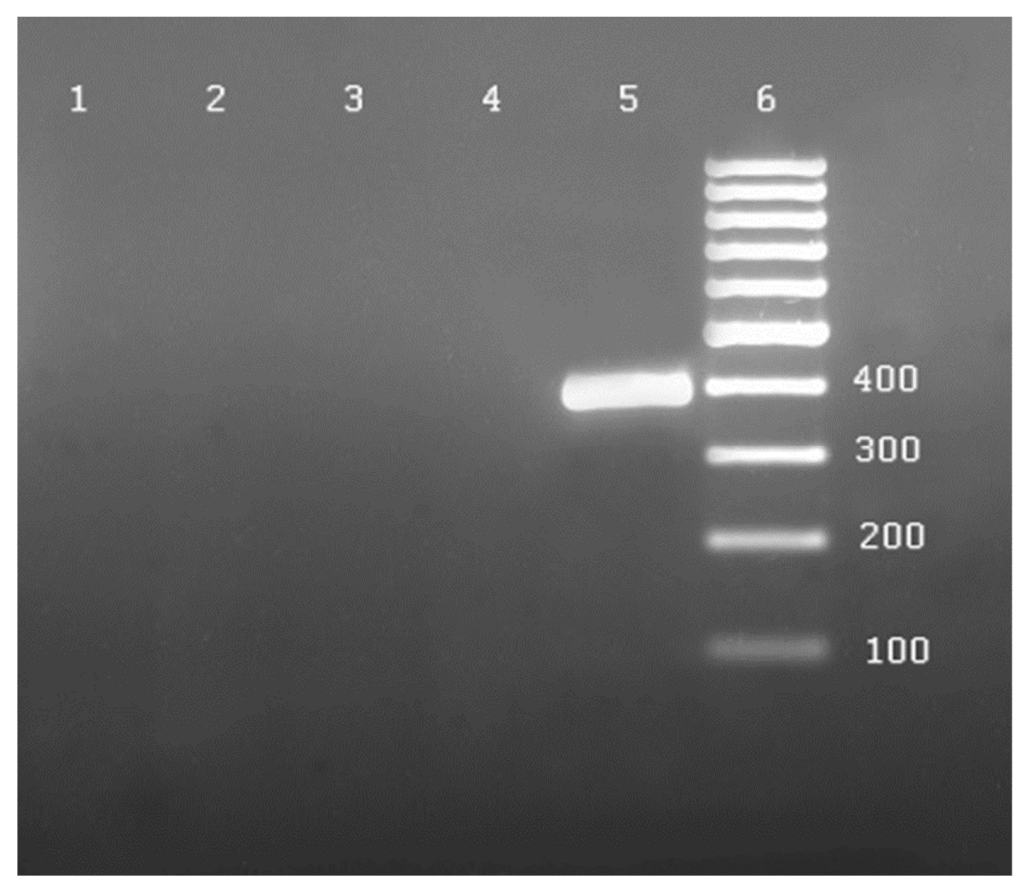

Figure 2. PCR products generated by amplification of the Nsyl-elF4E1 marker (402 bp) linked to the Va gene. Lanes:1, N. mutabilis; 2, N. alata; 3, N. forgetiana; 4, N. tabacum cv. VAM; 5, N. tabacum cv. Burley 21; 6, DNA ladder $100 \mathrm{bp}$.

\subsection{Resistance Response to TSWV}

The resistance response of $N$. mutabilis varied among plants at the same time points. Variations in the degree of infestation were also observed over time depending on the sampling date and the tested plant parts (Table 3).

Table 3. Resistance response of the tested species after TSWV inoculation depending on the sampling time and the part of the plant.

\begin{tabular}{|c|c|c|c|c|c|}
\hline Species & $\begin{array}{c}\text { Presence of Marker } \\
\text { ACC/CCC } 172\end{array}$ & Time of Sampling & Leaves & $\begin{array}{c}\text { No. of } \\
\text { ELISA-Positive/ } \\
\text { Tested Plants }\end{array}$ & Symptoms \\
\hline \multirow{6}{*}{ Nicotian mutabilis } & \multirow{6}{*}{+} & \multirow{3}{*}{ I } & lower & $39 / 40$ & $\mathrm{NeS}$ \\
\hline & & & middle & $30 / 40$ & $\mathrm{CS} / \mathrm{NeS}$ \\
\hline & & & upper & $10 / 40$ & $\mathrm{CS} / \mathrm{NeS}$ \\
\hline & & \multirow{2}{*}{ II } & middle & $31 / 40$ & $\mathrm{CS} / \mathrm{NeS}$ \\
\hline & & & upper & $5 / 40$ & $\mathrm{CS} / \mathrm{NeS}$ \\
\hline & & III & upper & $12 / 40$ & $\mathrm{CS} / \mathrm{NeS}$ \\
\hline \multirow{6}{*}{ Nicotiana alata } & \multirow{6}{*}{+} & \multirow{3}{*}{ I } & lower & $10 / 10$ & $\mathrm{NeS}$ \\
\hline & & & middle & $0 / 10$ & ns \\
\hline & & & upper & $0 / 10$ & ns \\
\hline & & \multirow{2}{*}{ II } & middle & $0 / 10$ & ns \\
\hline & & & upper & $0 / 10$ & ns \\
\hline & & III & upper & $0 / 10$ & ns \\
\hline
\end{tabular}


Table 3. Cont.

\begin{tabular}{|c|c|c|c|c|c|}
\hline Species & $\begin{array}{c}\text { Presence of Marker } \\
\text { ACC/CCC } 172\end{array}$ & Time of Sampling & Leaves & $\begin{array}{c}\text { No. of } \\
\text { ELISA-Positive/ } \\
\text { Tested Plants }\end{array}$ & Symptoms \\
\hline \multirow{6}{*}{ Nicotian forgetiana } & \multirow{6}{*}{+} & \multirow{3}{*}{ I } & lower & $10 / 10$ & $\mathrm{NeS}$ \\
\hline & & & middle & $10 / 10$ & WL \\
\hline & & & upper & $10 / 10$ & St \\
\hline & & \multirow{2}{*}{ II } & middle & $10 / 10$ & WL \\
\hline & & & upper & $10 / 10$ & St \\
\hline & & III & upper & $10 / 10$ & St \\
\hline \multirow{6}{*}{$\begin{array}{c}\text { Nicotiana tabacum } \\
\text { cv. VAM }\end{array}$} & \multirow{6}{*}{-} & \multirow{3}{*}{ I } & lower & $10 / 10$ & $\mathrm{VC} / \mathrm{CS}$ \\
\hline & & & middle & $10 / 10$ & $\mathrm{VC} / \mathrm{CS}$ \\
\hline & & & upper & $10 / 10$ & $\begin{array}{l}\text { St } \\
\text { CA }\end{array}$ \\
\hline & & \multirow{2}{*}{ II } & middle & $10 / 10$ & $\mathrm{VC} / \mathrm{CS}$ \\
\hline & & & upper & $10 / 10$ & $\begin{array}{c}\text { St } \\
\text { CA }\end{array}$ \\
\hline & & III & upper & $10 / 10$ & $\begin{array}{c}\mathrm{St} \\
\mathrm{CA}\end{array}$ \\
\hline \multirow{6}{*}{$\begin{array}{l}\text { Nicotiana tabacum } \\
\text { cv. Burley } 21\end{array}$} & \multirow{6}{*}{-} & \multirow{3}{*}{ I } & lower & $10 / 10$ & $\mathrm{VC} / \mathrm{CS}$ \\
\hline & & & middle & $10 / 10$ & $\mathrm{VC} / \mathrm{CS}$ \\
\hline & & & upper & $10 / 10$ & $\begin{array}{l}\text { St } \\
\text { CA }\end{array}$ \\
\hline & & \multirow{2}{*}{ II } & middle & $10 / 10$ & $\mathrm{VC} / \mathrm{CS}$ \\
\hline & & & upper & $10 / 10$ & $\begin{array}{l}\text { St } \\
\text { CA }\end{array}$ \\
\hline & & III & upper & $10 / 10$ & $\begin{array}{c}\mathrm{St} \\
\mathrm{CA}\end{array}$ \\
\hline
\end{tabular}

Lines: NeS, necrotic spots; CS, chlorotic spots; ns, no symptoms; WL, wrinkled leaves; VC, vein clearing; St, stunting; CA, curving of the apex. Time of sampling: I, 4 weeks; II, 8 weeks; III, 4 months after inoculation.

At the first time point (I), that is, four weeks after infection, $97.5 \%$ of $N$. mutabilis plants showed symptoms of hypersensitivity in the form of necrotic spots on their lower inoculated leaves. Simultaneously, the presence of TSWV was confirmed by DAS-ELISA tests. Chlorotic spots (CS) (Figure 3a) were observed on the middle uninoculated leaves of $75 \%$ of the plants, which then developed into necrotic spots (NeS) (Figures $3 b, c$ ) and the virus was detected by antibodies. In the remaining $25 \%$ of plants, the leaves of the middle uninoculated part remained healthy. At the first sampling date, it was shown that, in only one out of every four plants, the virus was detected in the upper uninoculated part of the plant.

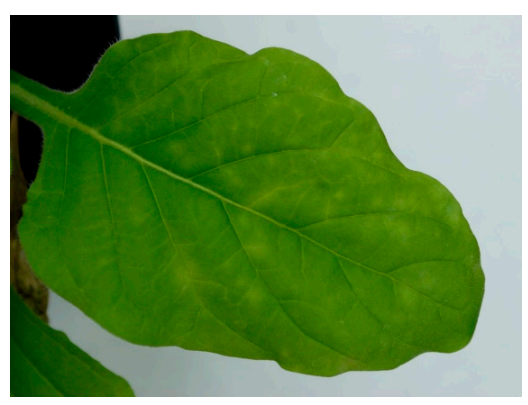

(a)

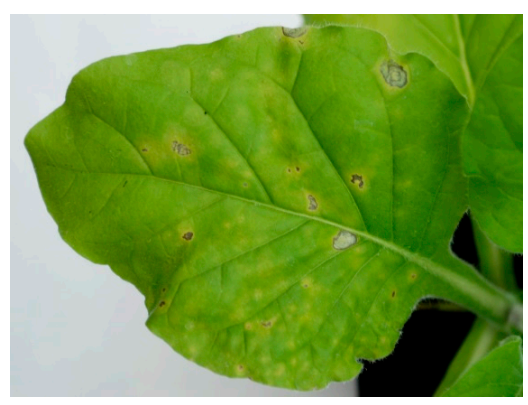

(b)

Figure 3. Cont. 


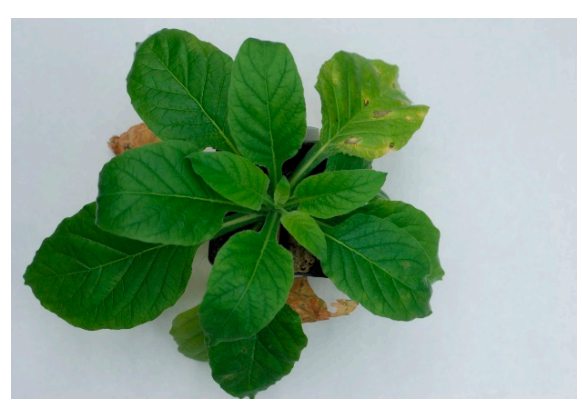

(c)

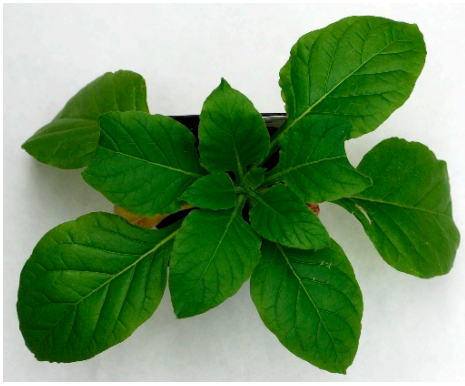

(d)

Figure 3. Response of Nicotiana mutabilis to TSWV four weeks after inoculation: (a) chlorotic spots (CS); (b,c) chlorotic and necrotic spots $(\mathrm{NeS})$; (d) mock inoculated plant without symptoms.

At the second time point (II), eight weeks after inoculation, only the middle and the upper leaves were examined, as those in the lower part of the plant had died. Our results showed that, in $77.5 \%$ of plants, the leaves of the middle uninoculated part were infected with TSWV, as evidenced by disease symptoms in the form of chlorotic and necrotic spots and a positive result of the DAS-ELISA test. Compared to time point I, the number of plants, for which the leaves from the upper uninoculated part showed disease symptoms, decreased to $12.5 \%$ and, in these plants, the virus was detected in the sap of the examined leaves.

At the third time point (III), four months after inoculation, samples were taken only from the upper uninoculated part, namely four of the youngest leaves at that particular time. The aim of the study was to determine whether the virus was still replicating and moving systematically beyond the necrotic tissue within the middle uninoculated part. Unfortunately, in $30 \%$ of the tested plants, chlorotic and necrotic spots were observed on the leaves of the upper uninoculated part and the presence of TSWV in these leaves was confirmed by DAS-ELISA. N. mutabilis plants inoculated only with buffer showed no disease symptoms (Figure 3d).

The other two species, N. alata and N. forgetiana, reacted differently from N. mutabilis. In the case of $N$. alata, typical hypersensitive symptoms in the form of necrotic spots were observed on the leaves of the lower segment of the inoculated plant four weeks after inoculation and the virus was serologically detected in that area (Figure 4). Conversely, leaves from the uninoculated middle and upper parts of plants of this species examined at time point I did not show any disease symptoms and the DAS-ELISA result was negative. Based on the results of the DAS-ELISA test, leaves collected after eight weeks and after four months were not infected by TSWV.

The course of infection was completely different in the case of $N$. forgetiana. Four weeks after inoculation, necrotic spots were noticed on the lower inoculated leaves of all ten tested plants, indicating a hypersensitive reaction. In this species, the uninoculated middle and upper leaves were also infected and the symptoms included leaf wrinkling and stunted plant growth (Figure 5). These symptoms also persisted at sampling dates II and III and the results of serological tests were positive for all samples. 


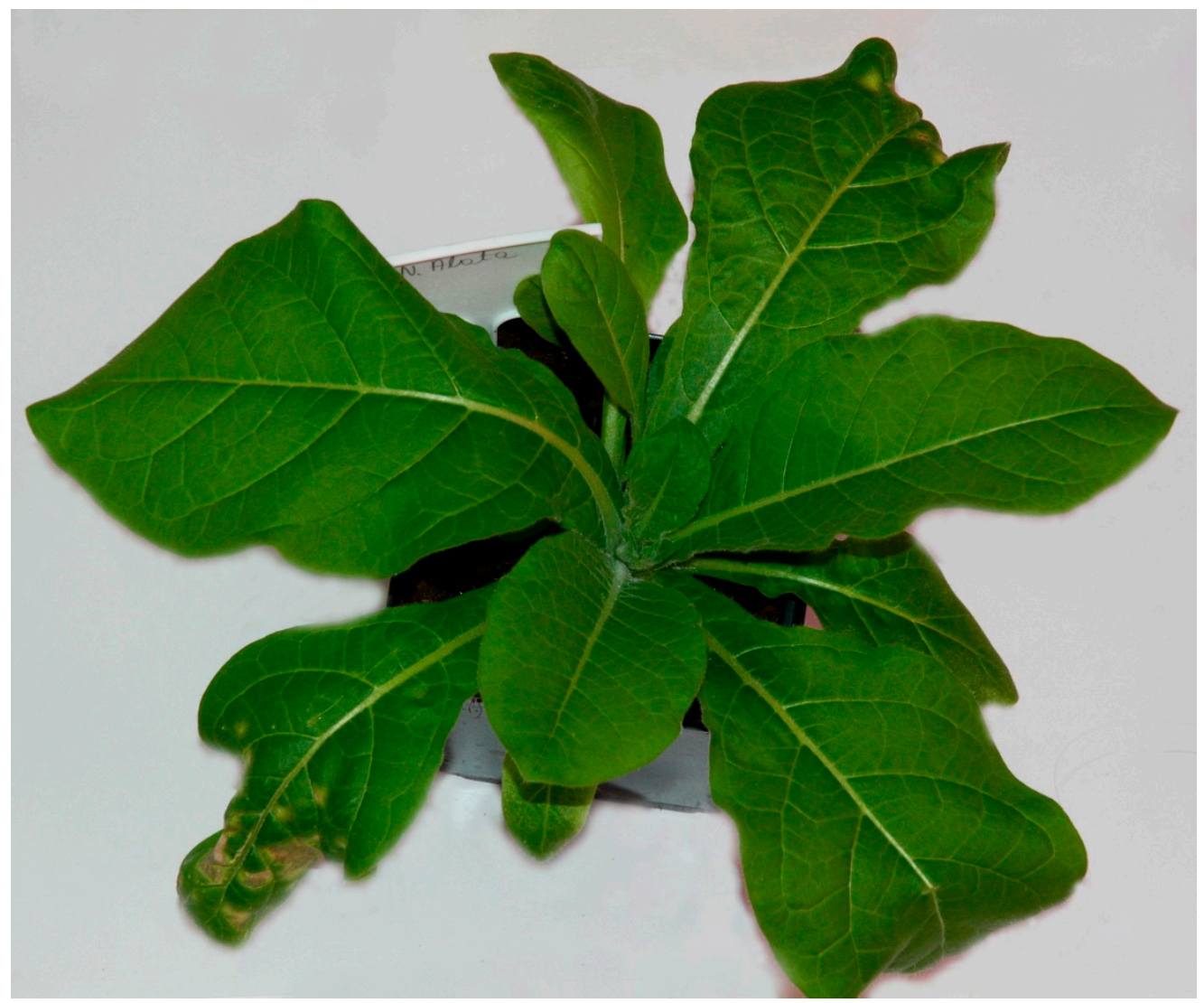

Figure 4. Hypersensitive symptoms shown as necrotic spots on lower leaves of N. alata four weeks after inoculation with TSWV.

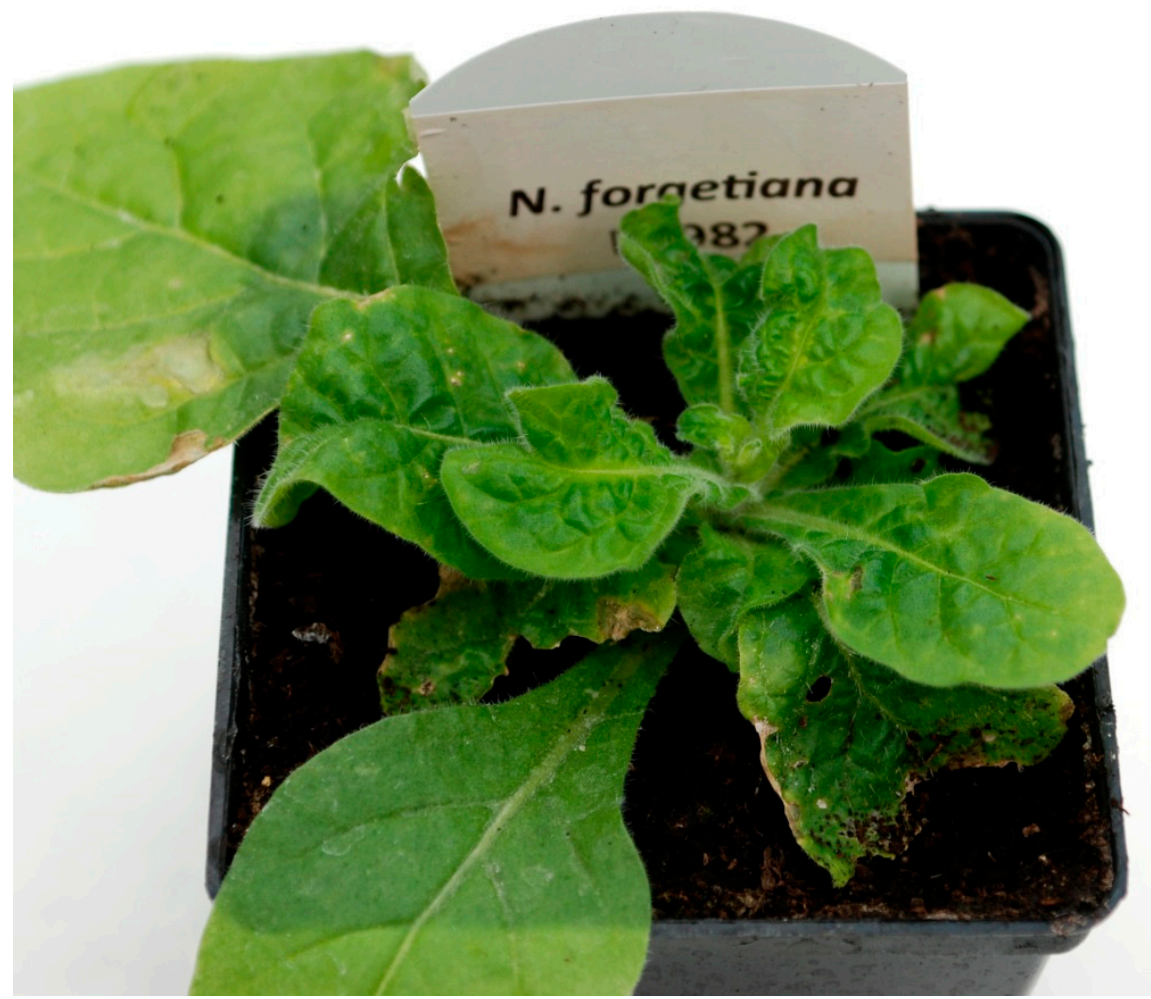

Figure 5. Wrinkled leaves and stunted growth as symptoms of TSWV infection in N. forgetiana species four weeks after inoculation. 
Two cultivars of Nicotiana tabacum, VAM and Burley 21, were included for TSWV resistance testing and responded with severe infection of the entire plants regardless of sampling time (Figure 6). As early as four weeks after inoculation, vein clearing and chlorotic spots occurred on the lower and middle leaves, while a bent apex and stunted plant growth were noted at the upper part. This trend was also observed on two later dates. TSWV was detected in all samples collected. Plants inoculated only with buffer showed no disease symptoms.

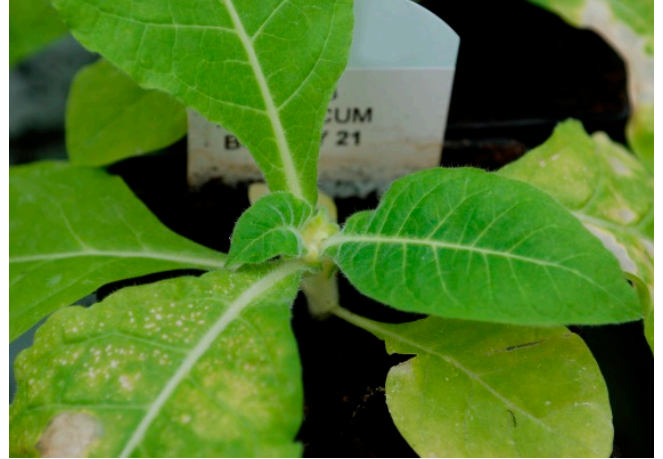

(a)

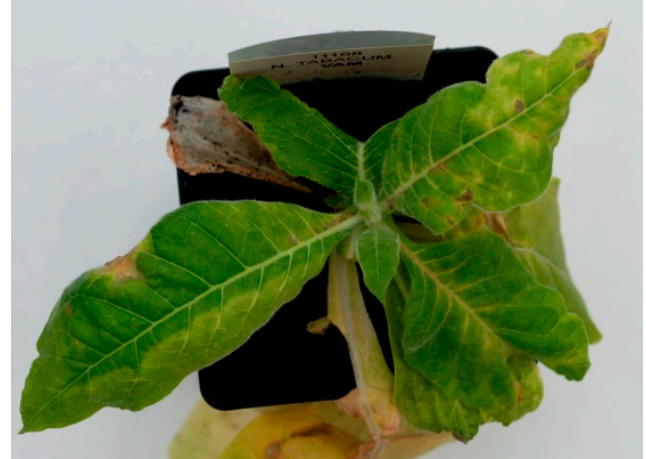

(b)

Figure 6. Stunted growth, chlorotic and necrotic spots of (a) tobacco cv. Burley 21 and (b)tobacco cv. VAM four weeks after TSWV inoculation.

The ACC/CCC 172 marker associated with TSWV resistance was detected in all tested N. mutabilis, N. alata and N. forgetiana plants (Figure 7). The tested Nicotiana tabacum cultivars did not include this marker (Table 3).

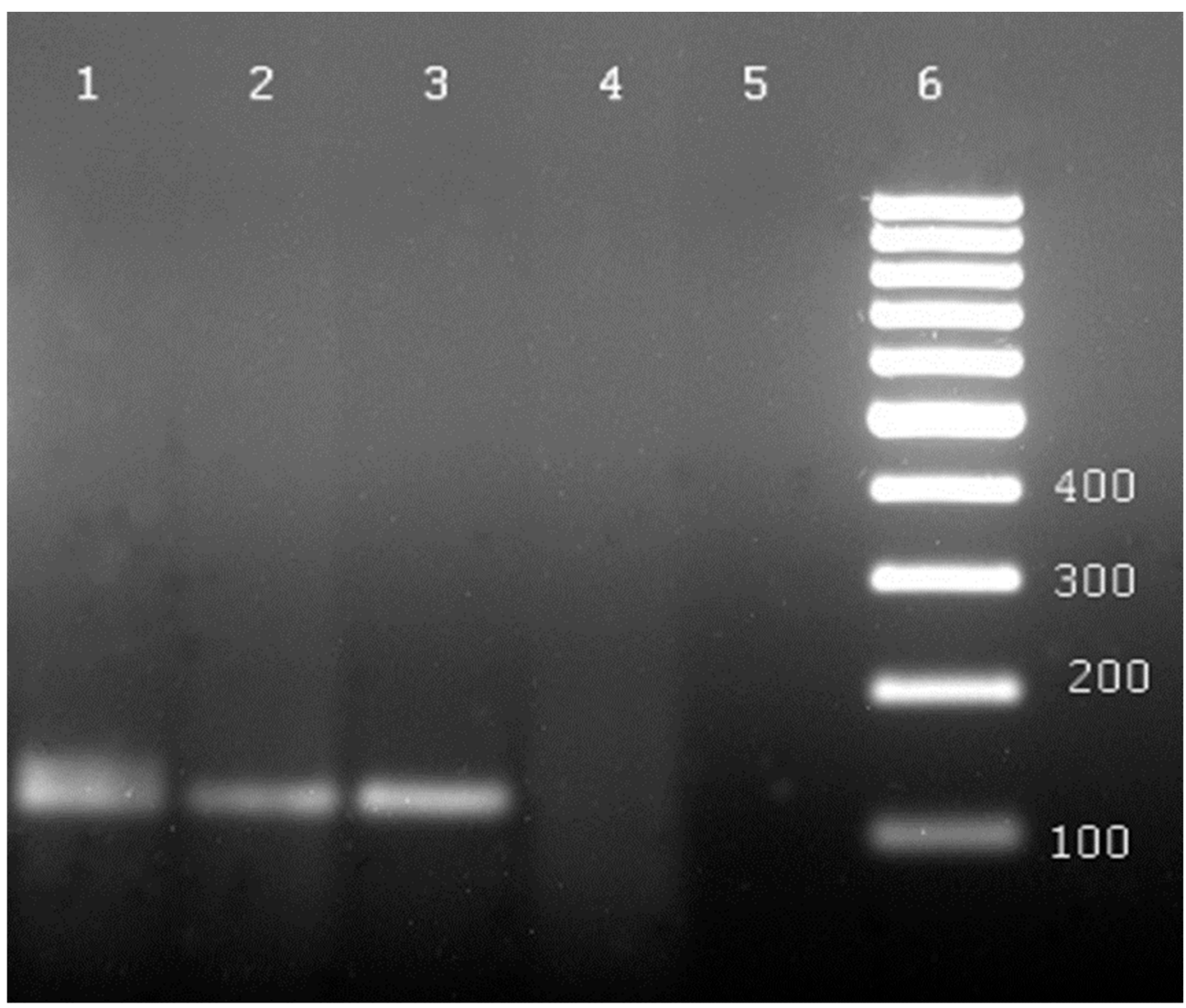

Figure 7. Amplification profiles generated by SCAR marker ACC/CCC 172 (117 bp) linked with the TSWV resistance gene. Lanes: 1, N. mutabilis; 2, N. alata; 3, N. forgetiana; 4, N. tabacum cv. VAM; 5, N. tabacum cv. Burley 21; 6, DNA ladder 100 bp. 


\section{Discussion}

The evaluation of resistance to PVY showed differences in symptom severity among the tested species depending on the PVY isolate used. Upon inoculation with two PVY ${ }^{N} W$ and PVY ${ }^{\text {NTN }}$ isolates, Nicotiana mutabilis reacted with only mild symptoms in the form of vein clearing. Cardin and Moury [58] examined 30 N. mutabilis plants found in a nursery in the south of France. The tested plants showed mosaic symptoms and vein clearing on leaves. Electron microscope observations and DAS-ELISA tests indicated the presence of PVY and further tests showed the presence of the PVYC isolate. The resistance tests presented here by us are more detailed, because they were performed under controlled conditions. Moreover, two PVY isolates of different virulence were used. The molecular analysis of N. mutabilis did not reveal the presence of the Nsyl-elF4E1 marker, indicating the absence of $V a$-type susceptibility. This was found in susceptible cultivar Burley 21, which showed vein necrosis as an effect of infection by both mild and severe isolates. PVY resistance of some $N$. tabacum cultivars is determined by a recessive va gene that resulted from a genomic deletion within the susceptibility gene [57]. No PCR product was amplified in the resistant cultivar VAM, confirming the deletion within the susceptibility gene $\mathrm{Va}$. This cultivar, however, showed no disease symptoms after inoculation with the milder isolate, while the severe one caused necrosis.

Similar resistance response to that of $N$. mutabilis was observed in two other related species, i.e., N. alata and N. forgetiana. Previously, when infected with six PVY isolates, $N$. alata and $N$. forgetiana showed disease symptoms, such as vein clearing, chlorotic spots, mosaic discolouration and leaf deformations [31]. None of the isolates caused vein necrosis in species within the section Alatae. The absence of necrosis after PVY inoculation is a tolerance trait and also occurs within the species $N$. tabacum. In tolerant tobacco cultivars, such as Virginia SP278 and Zamojska 4, this trait is conferred by a single recessive gene, NtTPN1 [28]. Since PCR products corresponding to the $v a$ gene were not identified in N. mutabilis, N. alata and N. forgetiana, the genetic basis of their tolerance to PVY remains unknown. Based only on the occurrence of similar symptoms, however, it can be assumed that $N$. mutabilis has a source of resistance similar to that of N. alata and N. forgetiana.

The response of the tested plants of N. mutabilis to TSWV varied depending on the sampling date, as well as the plant part. So far, there are very few data in the literature regarding the resistance of $N$. mutabilis to TSWV. The present study determined that this species reacted with hypersensitivity to TSWV, confirming the close affinity of N. mutabilis to the species N. alata and N. forgetiana, which belong to the same section [6]. Four weeks after inoculation, necrotic spots, indicative of a hypersensitive reaction, occurred on the lower leaves of 39 plants out of the 40 tested, on the middle leaves of 30 plants and on the upper leaves of 10 plants. The formation of necrotic spots was preceded by the appearance of chlorotic spots. After eight weeks, the leaves of the middle part of 31 plants were infected and only 5 plants had the virus in the leaves of the upper part. The fact that the youngest leaves were infected in fewer plants indicates virus retention in the lower leaves. Four months after inoculation, the virus was present in the upper leaves of 12 plants. This indicates that systemic infection of a plant may still occur long after inoculation.

A hypersensitive reaction also occurred in all tested $N$. alata and $N$. forgetiana plants. The disease symptoms of these two species, however, differed significantly with time. In the case of N. alata, necrotic spots occurred only on the lower leaves, while the rest remained healthy on all plants throughout the entire period of testing. The study by Laskowska et al. included seven populations of $N$. alata from different countries. The researchers indicated that all plants from two populations reacted only with a hypersensitive response. As for the rest, TSWV caused systemic infection of $6.3-50.0 \%$ of plants. The instability of this form of resistance is not fully explained. One reason may be the self-incompatibility of the studied species in the section Alatae, resulting in lack of full homozygosity [49]. The close relationship of $N$. mutabilis to $N$. alata may explain the similar differential resistance response to TSWV. Therefore, further genetic evaluation of N. mutabilis is desired. In $N$. forgetiana, which we tested in our study, despite the hypersensitivity reaction in the first 
phase of infection, a systemic reaction occurred and TSWV was detected in the entire plant after four weeks. Previous research by Laskowska et al. [49] on the same species showed similar results.

Molecular studies have shown that the SCAR marker ACC/CCC 172 [50] associated with TSWV resistance is amplified in all tested N. mutabilis plants, as well as the other two species from the section Alatae examined here. Although the resistance response of these species is not identical, in all cases, hypersensitivity at the initial stage of infection was recorded. Simultaneously, marker ACC/CCC 172 was not detected in cultivated tobacco varieties that are susceptible to TSWV. Therefore, prospecting for sources of resistance to TSWV that could be used in tobacco breeding is very important.

Over the years, many attempts have been made to transfer TSWV resistance from N. alata to cultivated tobacco. Such work was undertaken by Gajos [59], who crossed $N$. tabacum with $N$. alata. As a result of the particular selection of breeding lines, he obtained a cultivar in the dark cigarette type-Polalta [60]—and a cultivar in the light cigarette type-Wiktoria [61] - which contained the resistance factor from N. alata. According to Yancheva [62], TSWV resistance from cv. Polalta was inherited as a single dominant gene, but the resulting hybrid plants showed morphological deformations which significantly limited the possibility of using this source of resistance in breeding. Later attempts to transfer resistance genes from Nicotiana alata to cultivated tobacco were made on multiple occasions [63-66].

As shown by the authors of the studies cited, obtaining cultivars resistant to TSWV is extremely important, but also very difficult. Previous work has solely focused on resistance derived from N. alata. The aim of our study was to evaluate the resistance of a recently discovered and, thus far, untested species. The affinity of N. mutabilis to N. alata and the confirmed presence of the SCAR marker ACC/CCC 172 indicate the need for more extensive studies. This is the first time such a detailed resistance test of $N$. mutabilis has been carried out and our results show that this species can be used as a potential source of resistance to TSWV, thus expanding the pool of genetic variability.

\section{Conclusions}

Tests for PVY resistance showed that the species N. mutabilis was tolerant to two PVY strains. Evaluation of resistance to TSWV demonstrated the hypersensitive reaction of this species but, nevertheless, the systemic infection of some plants was also observed. Due to PVY tolerance and its partial resistance to TSWV, N. mutabilis may be a potential source of resistance in tobacco breeding.

Author Contributions: Conceptualisation, A.D.; methodology, A.D. and A.C.; validation, A.D.; formal analysis, A.D., T.D. and A.C.; investigation, A.D., T.D. and A.C.; resources, A.D., T.D. and A.C.; data curation, A.D.; writing-original draft preparation, A.D.; writing-review and editing, A.C. and T.D.; visualisation, A.D.; supervision, T.D.; project administration, A.D. and A.C.; funding acquisition, T.D. All authors have read and agreed to the published version of the manuscript.

Funding: The study was financed by a targeted grant from the Ministry of Agriculture and Rural Development for 2021 in the area "Protection of plant genetic resources of agricultural plants" coordinated by the Institute of Plant Breeding and Acclimatization-National Research Institute.

Institutional Review Board Statement: Not applicable.

Informed Consent Statement: Not applicable.

Data Availability Statement: Not applicable.

Conflicts of Interest: The authors declare no conflict of interest.

\section{References}

1. Doroszewska, T.; Depta, A.; Czubacka, A. Album of Nicotiana Species; Institute of Soil Science and Plant Cultivation: Puławy, Poland, 2009.

2. Kostoff, D. The origin of the tetraploid Nicotiana from Bathurst. Cur. Sci. 1939, 8, 110-111. 
3. Goodspeed, T.H. The genus Nicotiana; Chronica Botanica: Waltham, MA, USA, 1954.

4. Burbidge, N.T. The Australian species of Nicotiana L. (Solanaceae). Aust. J. Bot. 1960, 8, 342-380. [CrossRef]

5. Merxmüller, H.; Buttler, L.P. Nicotiana in der Afrikanischen Namib-Ein Pflanzen geographisches und phylogenetisches Ratsel. Itl. Bot. 1975, 12, 91-104.

6. Knapp, S.; Chase, M.; Clarkson, J.J. Nomenclatural changes and a new sectional classification in Nicotiana (Solanaceae). Taxon 2004, 53, 73-82. [CrossRef]

7. Lewis, R.S.; Nicholson, J.S. Aspects of the evolution of Nicotiana tabacum L. and the status of the United States Nicotiana Germplasm Collection. Genet. Resour. Crop Evol. 2007, 54, 727-740. [CrossRef]

8. Stehmann, J.R.; Semir, J.; Ippolito, A. Nicotiana mutabilis (Solanaceae), a new species from southern Brazil. Kew Bull. 2002, 57, 639-646. [CrossRef]

9. Doroszewska, T.; Berbeć, A. Methodology of Tobacco Integrated Pest Management; Institute of Soil Science and Plant Cultivation: Puławy, Poland, 2015. (In Polish)

10. Doroszewska, T. Wide Hybridization and Genetic Transformation in Breeding for Resistance to Potato virus Y (PVY) in Tobacco (Nicotiana tabacum L.); Institute of Soil Science and Plant Cultivation: Puławy, Poland, 2004.

11. Scholthof, K.B.K.; Adkins, S.; Czosnek, H.; Palukaitis, P.; Jacquot, E.; Hohn, T.; Hohn, B.; Saunders, K.; Candresse, T.; Ahlquist, P.; et al. Top 10 plant viruses in molecular plant pathology. Mol. Plant Pathol. 2011, 12, 938-954. [CrossRef]

12. Simmonds, P.; Aiewsakun, P. Virus classification-Where do you draw the line? Arch. Virol. 2018, 163, 2037-2046. [CrossRef]

13. Gorbalenya, A.E.; Krupovic, M.; Mushegian, A.; Kropinski, A.M.; Siddell, S.G.; Varsani, A.; Adams, M.J.; Davison, A.J.; Dutilh, B.E.; Harrach, B.; et al. The new scope of virus taxonomy: Partitioning the virosphere into 15 hierarchical ranks. Nat. Microbiol. 2020, 5, 668-674.

14. Robaglia, C.; Durand-Tardif, M.; Tronchet, M.; Boudazin, G.; Astier-Manifacier, S.; Casse-Delbart, F. Nucleotide sequence of Potato virus Y (N strain) genomic RNA. J. Gen. Virol. 1989, 70, 935-947. [CrossRef]

15. Thole, V.; Dalmay, T.; Burgyan, J.; Balazs, E. Cloning and sequencing of Potato virus Y (Hungarian isolate) genomic RNA. Gene 1993, 123, 149-156. [CrossRef]

16. Green, K.J.; Brown, C.J.; Gray, S.M.; Karasev, A.V. Phylogenetic study of recombinant strains of Potato virus Y. Virology 2017, 507, 40-52. [CrossRef]

17. Chrzanowska, M. Differentiation of Potato virus Y (PVY) isolates. Phytopathol. Pol. 1994, 8, 15-20.

18. Le Romancer, M.; Kerlan, C.; Nedellec, M. Biological characterization of various geographical isolates of Potato virus $Y$ inducing superficial necrosis on potato tubers. Plant Pathol. 1994, 43, 138-144. [CrossRef]

19. Tribodet, M.; Glais, L.; Kerlan, C.; Jacquot, E. Characterization of Potato virus Y (PVY) molecular determinants involved in the vein necrosis symptom induced by PVYN isolates in infected Nicotiana tabacum cv. Xanthi. J. Gen. Virol. 2005, 86, 2101-2105. [CrossRef]

20. Crosslin, J.M. PVY: An Old Enemy and A Continuing Challenge. Am. J. Potato Res. 2013, 90, 2-6. [CrossRef]

21. Gugerli, P.; Fries, P. Characterization of monoclonal antibodies to Potato virus $Y$ and their use for virus detection. J. Gen. Virol. 1983, 64, 2471-2477. [CrossRef]

22. Drake, J.W. Rates of spontaneous mutation among RNA viruses. Proc. Natl. Acad. Sci. USA 1993, 90, 4171-4175. [CrossRef] [PubMed]

23. Przybyś, M.; Doroszewska, T.; Berbeć, A. Point mutation in the viral genome-linked protein (VPg) of Potato virus $Y$ probably correspond with ability to overcome resistance of tobacco. J. Food Agric. Environ. 2013, 11, 986-989.

24. Dluge, K.L.; Song, Z.; Wang, B.; Steede, W.T.; Xiao, B.; Liu, Y.; Dewey, R.E. Characterization of Nicotiana tabacum genotypes possessing deletion mutations that affect potyvirus resistance and the production of trichome exudates. BMC Genom. 2018, 19, 484. [CrossRef] [PubMed]

25. Ruyi, R.; Qiang, Z.; Futai, N.; Qiu, J.; Wiuqing, W.; Jicheng, W. Breeding for PVY resistance in tobacco LJ911 using CRISPR/Cas9 technology. Crop Breed. Appl. Biotechnol. 2021, 21, e31682116. [CrossRef]

26. Julio, E.; Cotucheau, J.; Decorps, C.; Volpatti, R.; Sentenac, C.; Candresse, T.; Dorlhac de Borne, F. A eucariotic translation initiation factor 4E (elF4E) is responsible for the "va" tobacco recessive resistance to potyviruses. Plant. Mol. Biol. Rep. 2015, 33, 609-623. [CrossRef]

27. Koelle, G. Versucherzur Vererbung der Krankheitsresistenz bei Tabak. 2 Mitt. Eine Rippen-braune-resistante Virgin A Mutante nach Anwendung kunstlicher Mutations auslosung durch Rontgenstrahlen. Table Forsch. 1958, 24, 83-84.

28. Michel, V.; Julio, E.; Candresse, T.; Cotucheau, J.; Decorps, C.; Volpatti, R.; Moury, B.; Glais, L.; Dorlhac de Borne, F.; Decroocq, V.; et al. NtTPN: A RPP8-like R gene required for Potato virus $Y$-induced veinal necrosis in tobacco. Plant J. 2018, 95, 700-714. [CrossRef]

29. Verrier, J.L.; Doroszewska, T. Tobacco Virus Collaborative Study (1996-2011) VIR Technical Report. 2018. Available online: https:/ / www.coresta.org/documents /search?f\%5B0\%5D=im_field_technical_document_type\%3A36193\&page=5 (accessed on 1 August 2018).

30. Sievert, R.C. Sources of resistance to Potato virus $Y$ in the genus Nicotiana. Tob. Sci. 1972, 106, 92-94.

31. Doroszewska, T.; Depta, A. Resistance of wild Nicotiana species to different PVY isolates. Phytopathologia 2011, 59, 9-24.

32. Doroszewska, T.; Chrzanowska, M. Characterization of the main PVY resistance sources to different PVY strains. Inf. Bull. Coresta 2001, 60, 21-27. 
33. Wersman, E.A. Varied Roles of the Haploid Sporophyte in Plant Improvement. In Plant Breeding in the 1990s; Stalker, H.T., Murphy, J.P., Raleigh, N.C., Eds.; CABI Publ.: Wallinfort, UK, 1992; pp. 461-484.

34. Lewis, R.S. Transfer of resistance to Potato virus Y (PVY) from Nicotiana africana to Nicotiana tabacum: Possible influence of tissue culture on the rate of introgression. Theor. Appl. Genet. 2005, 110, 678-687. [CrossRef]

35. Lewis, R.S. Evaluation of Nicotiana tabacum genotypes possessing Nicotiana africana-derived genetic tolerance to Potato Virus $Y$. Crop Sci. 2007, 47, 1975-1984. [CrossRef]

36. Doroszewska, T. Transfer of tolerance to different Potato virus Y (PVY) isolates from Nicotiana Africana Merxm. to Nicotiana tabacum L. Plant Breed. 2010, 129, 76-81. [CrossRef]

37. Korbecka-Glinka, G.; Czubacka, A.; Przybyś, M.; Doroszewska, T. Resistance vs. tolerance to Potato virus Y in tobacco-Comparing effectiveness using virus isolates from Central Europe. Breed. Sci. 2017, 67, 459-465. [CrossRef] [PubMed]

38. Korbecka-Glinka, G.; Czubacka, A.; Depta, A.; Doroszewska, T. Inheritance of Potato virus Y tolerance introgressed from Nicotiana africana to cultivated tobacco. Pol. J. Agron. 2017, 31, 39-44.

39. Parella, G.; Gognalons, P.; Gebre-Sellassie, K.; Vovlas, C.; Marchoux, G. An update of the host range of Tomato spotted wilt virus. J. Plant Pathol. 2003, 85, 227-264.

40. Francki, R.I.B.; Fauquet, C.M.; Knudson, D.D.; Brown, F. Fifth report of the International Committee on Taxonomy of Viruses. Arch. Virol. 1991, 2, 1-450.

41. Wijkamp, I.; Van Lent, J.; Kormelink, R.; Goldbach, R.; Peters, D. Multiplication of Tomato spotted wilt virus in its insect vector, Frankliniella occidentalis. J. Gen.Virol. 1993, 74, 341-349. [CrossRef] [PubMed]

42. Jones, D.R. Plant viruses transmitted by thrips. Eur. J. Plant Pathol. 2005, 113, 119-157. [CrossRef]

43. Mumford, R.A.; Barker, I.; Wood, K.R. The biology of the tospoviruses. Ann. Appl. Biol. 1996, 128, 159-183. [CrossRef]

44. Doroszewska, T.; Berbeć, A.; Czarnecka, D.; Kawka, M. Diseases and Pests of Tobacco; Institute of Soil Science and Plant Cultivation: Puławy, Poland, 2013.

45. Ivancheva-Gabrovska, T. Sources of resistance to Tomato spotted wilt virus and Thrips tabaci Lind. Spec. CORESTA Bull Symp. Sofia 1978, 96 .

46. Jankowski, F. Sources of resistance to TSWV (Lycopersicum virus 3) among uncultivated species of Nicotiana genus. Biul CLPT 1980, 1-2, 3-8.

47. Kovalenko, A.G.; Rud, E.A.; Strelyaeva, N.I.; Oleshchenko, L.T. Responses of tobacco varieties, wild species and interspecies hybrids on artificial infection with Tomato spotted wilt virus. Mikrobiol. Zhurnal. 1987, 49, 85-89.

48. Palakarcheva, M.; Yancheva, A. Genetic sources of resistance to tomato bronziness pathogen on tobacco in wild species of the genus Nicotiana. Genet Breed 1989, 22, 473-479. (In Bulgarian)

49. Laskowska, D.; Doroszewska, T.; Depta, A.; Kursa, K.; Olszak-Przybyś, H.; Czubacka, A. A survey of Nicotiana germplasm for resistance to Tomato spotted wilt virus (TSWV). Euphytica 2013, 193, 207-219. [CrossRef]

50. Moon, H.; Nicholson, J.S. AFLP and SCAR markers linked to Tomato Spotted Wilt Virus resistance in tobacco. Crop Sci. 2007, 47, 1887-1894. [CrossRef]

51. Koelle, G. Genetische Analyse einer Y-virus (Rippen-braune) resistenten Mutante der Tabaksorte Virgin A. Zuchter 1961, 31, 71-72.

52. Chrzanowska, M.; Doroszewska, T. Comparison between PVY isolates obtained from potato and tobacco plants in Poland. Phytopathol. Pol. 1997, 13, 63-71.

53. Doroszewska, T.; Verrier, J.L. Sub-Group Collaborative Study on Potato Virus Y; Annual Subgroup Report; CORESTA CD-ROM Version. 20; Paris, France, 2004.

54. Verrier, J.L. PVY Collaborative Experiment. Results; Altadis, Insitute du Tabac: Bergerac, France, 2001.

55. Tsakiridis, J.P.; Gooding, G.V. Tomato spotted wilt virus in Greese. Phytopathol. Mediterr. 1972, 11, $42-47$.

56. Doyle, J.J.; Doyle, J.L. A rapid DNA isolation procedure from small quantities of fresh leaf tissue. Phytochem. Bull. 1987, 19, 11-15.

57. Sierro, N.; Battey, J.N.D.; Ouadi, S.; Bakaher, N.; Bovet, L.; Willing, A.; Geopfert, S.; Peitsch, M.C.; Ivanov, N.V. The tobacco genome sequence and its comparison with those of tomato and potato. Nat. Commun. 2014, 5, 3833. [CrossRef]

58. Cardin, L.; Moury, B. First Report of Potato virus Y in Nicotiana mutabilis in France. Plant Dis. 2008, 92, 312. [CrossRef]

59. Gajos, Z. Inheritance of resistance to Tomato spotted wilt virus in interspecies hybrids of Nicotiana tabacum $\times$ Nicotiana alata Link. Zesz. Prob. Post. Nauk Rol. 1981, 244, 117-126.

60. Gajos, Z. Polalta, the first Polish tobacco variety resistant to Tomato spotted wilt virus was released for regional experimentation and propagation. Wiad. Tytoniowe. 1987, 31, 11-17.

61. Gajos, Z. Virginia ZG-4 (Wiktoria)-A new tobacco variety resistant to Tomato spotted wilt virus (TSWV) and black root rot (Thielaviopsisbasicola Ferr.). Biul. CLPT 1993, 1-4, 5-19.

62. Yancheva, A.A. Possibility for transferring combined resistance to Tomato spotted wilt virus and Thielaviopsis basicola to intercultivar tobacco hybrids. Genet. Breed. 1990, 23, 194-199. (In Bulgarian)

63. Berbeć, A. Cytological study on Nicotiana tabacum L. cv. Nadwiślański Mały $(2 \times$ and $4 \times) \times$ Nicotiana alata Link et Otto hybrids. Genet. Pol. 1987, 28, 251-261.

64. Laskowska, D.; Berbeć, A. Cytology and fertility of viable hybrids of Nicotiana tabacum L. cv. TB-566 with N. alata Link et Otto. J. Appl. Genet. 2005, 46, 11-18. 
65. Laskowska, D.; Berbeć, A. Resistance to Tomato spotted wilt virus (TSWV) in Nicotiana alata and N. sanderae and in hybrids between N. tabacum and N. alata. Plant Breed. Seed Sci. 2006, 54, 91-100.

66. Laskowska, D.; Berbeć, A. TSWV resistance in DH lines of tobacco (Nicotiana tabacum L.) obtained from a hybrid between 'Polalta' and 'Wiślica'. Plant Breed. 2010, 129, 731-733. [CrossRef] 